\title{
Islamic Moderation Values within ELT in a Higher Education Context
}

\author{
Daviq Rizal \\ UIN Walisongo Semarang, Indonesia \\ \{daviqr@walisongo.ac.id\}
}

\begin{abstract}
Islamic moderation has received a great deal of attention both in the west and in the east to resolve different religious conflicts[1][2]. Scholars and coursebook writers had included Islamic moderation values in the coursebooks of Islamic religious studies[3]. Besides, Islamic institutions had applied moderate Islamic understanding through Aswaja An-Nahdliyyah character education[4]. In ELT, lecturers of English subjects had instilled Islamic moderation values in teaching speaking through group-work activity[5]. Also, some lecturers had integrated Islamic values into learning English[6]. By using qualitative metadata analysis, the research on the moderate moderation values in ELT in a Higher Education context was investigated by using journal papers the primary data. The results showed that no school or universities in Malaysia, the Philliphines, Singapore, or Vietnam integrate Islamic moderation values within English language teaching. Only in Indonesia, a few Islamic institutions including Islamic universities or schools integrate Islamic moderation values in English language teaching.
\end{abstract}

Keywords: Islamic Moderation Values; ELT; English; Higher Education

\section{Introduction}

Islamic moderation has received a great deal of attention both in the west and in the east to resolve different religious conflicts[1][2] by implementing Islamic moderation values inside and outside universities with dialogues and strategic advocation as radicalism threatens harmony and unity[7]. 'Islamic moderation' and 'moderate Muslim' and 'moderate Islam' are highly contextualized words since various denotation sheds are given by various regions and contexts. However, media and academia generated these particular vocabulary at the backdrop of the 1979 Iranian revolution to describe Muslims, Islam and Islamists and their relationship with the West. In this sense,' Moderation' was discovered by specialists as an appropriatelanguage to deal with the then newly emerging situation. Since then, it has become a catchword for writers, academics, politicians and policy-makers alike. For example, the term "soft Islamists" (as opposed to "hard-line Islamists") originated from Geneive Abdo, an American journalist of Middle East descent. It was quickly embraced by some of her fellow journalists[8]. Islamic moderation values have not been integrated with English language teaching as in 2004 curriculum, the competency-based language program emphasizes performance-based results in forms of national standards for each educational unit from 
primary to high school. This new approach demands excessive versatile, independent learning. However, this approach has contributed to several problems due to a variety of cultural, technical and realistic factors[9]. In Malaysia, the Islamic moderation values were not really clarified and incorporated into the ELT curriculum, as the government only highlighted the paradigmatic change from knowledge-based root learning to self-access learning that encouraged independence and lifelong learning, and manpower that can think creatively and critically by using the Smart Schools Project and the comprehensive reading programs[10]. Also in Singapore, the Islamic moderation values were not integrated into English language teaching as a new English syllabus for Singapore schools excluding the values was introduced in 2001, one described as "evolutionary" and not "revolutionary". This reassurance for teachers follows a decade of immense educational reform and helps to highlight the importance of the Ministry of Education ( MOE) in consolidating and building on past philosophies and traditions of English language teaching (ELT). The year 2000 also marked the liberalization of the primary school textbook market, the first since the $1980 \mathrm{~s}$, and schools now have a variety of textbooks instead of either one or two names, as was the case[11].

Moderate Islam is an antidote to radical Islam; therefore the two terms are contradistinctive[12]. According to those journalists (and some of them, too), so-called moderate Islamists are not anti-Western. For example, Afshin Molavi, an American journalist of Iranian descent who reviewed Ms. Abdo 's book for The Washing-ton Post, recounts that he (the journalist) was traveling to Egypt shortly after the publication of Professor Samuel P. Huntington 's essay, "The Clash of Civilizations" (1993), where the authorities were worried about the emergence of a "moderate" Islamist opposition. A local journalist invited him to meet a "moderate Islamist scholar," who said Professor Huntington was right, adding, "Islam and the West are fundamentally incompatible. The American journalist commented, "The Khrushchevian touch was a little too obvious: I later discovered that the so-called moderate scholar collaborated with the Egyptian Intelligence Ministry and the journalist in a temptation to show foreign journalists the ugly, furious, and violently anti-Western face of Egypt's Islamic opposition[8]." Another term related to moderation is al wasatiyah. The term alwasatiyyah derives from a middle, equal, just, moderate, middle and setting Arabic word wasat. In the Qura $\bar{n}$, the term in its various forms is used in many con-texts, all of which revolve around identical linguistic meanings. Wasatiyah (Islamic moderation) is one of the principles used in Islamic epistemology. Based on al-wasatiyah 's meaning, which in Arabic means "middle," this term creates a moderate, equitable and best approach. It seeks to balance extreme and fanatical behavior in every area of man's life[13].

In East Java, Indonesia, Islamic moderation values were taught in one of the schools in which three main principles were shown: tawasuth-middle, ta'adul-fair, and tawazunbalance[14]. In Jepara -based school, the principles taught were tawasuth-middle, ta'adul-fair, tawazun-balance and tasamuh. Tawassuth is taught by the duty to pray before the lesson starts, orderly running picket, orderly going to class, and even orderly praying in congregation midday prayer. Furthermore, tawazun is performed by wearing uniforms decided and loving ancestor community. Tasamuh is introduced by orderly practice in parking motorbikes, fostering greetings, greetings, orphans and needy people. Finally, ta'adul's value was precipitated by class cleanliness, terraces, madrasa pages, and bans on graffiti littering the walls[4]. In Surabaya, Malang and Pasuruan, East Java, some teachers of Islamic junior high schools (widely known as Madrasah Tsanawiyah) integrated Islamic values in the English lessons in their religious routines such as praying together, reciting some surah, and other Islamic routines[15]. 
Scholars and textbook writers had included Islamic moderation values in the coursebooks of Islamic religious studies[3]. Islamic university students had integrated Islamic values into their communication styles in the Edmodo learning atmosphere. Besides, the use of Islamic terms and the existence of Islamic values in the English conversations make the online learning group differ from other online communities[16]. The research is to find out the integration of Islamic moderation values within English language teaching in South-East Asia.

\section{Method}

By using qualitative metadata analysis, the moderate moderation values in ELT in a Higher Education context were investigated by using scientific journal papers discussing Islamic moderation values and ELT as the primary data. Qualitative meta-analysis is an attempt to evaluate secondary qualitative analysis of primary qualitative findings by providing a more comprehensive description of a phenomenon on findings. The basic concept of qualitative meta-analysis is to provide a succinct and detailed picture of findings through qualitative studies that examine the same general research subject[17]. As Schreiber, Crooks, and Stern [18] suggest, qualitative meta-analysis is defined by "the aggregating of a group of studies for the purposes of discovering the basic elements and converting the findings into an end product that converts the original findings into a new conceptualization'. Another qualitative metaanalysis theoretician, Finfgeld [19] characterized qualitative meta-analysis as "a new and integrative view of results that is more substantive than those arising from individual investigations". Qualitative meta-analysis follows the same rationale and objective as quantitative meta-analysis, namely to determine a field of research beyond one specific study. However, this approach considers only qualitative or, as pointed out later, at least partly qualitative research. While quantitative meta-analysis aims to bring more detailed estimates of ' ' real' 'parameters of quantitative outcomes recorded in primary studies, qualitative metaanalysis attempts to perform a systematic secondary qualitative analysis of primary qualitative findings[17].

The journal articles on Islamic moderation values and English language teaching in SouthEast Asia were analyzed and discussed. The analysis is on the practice and the integration of Islamic moderation values in inside universities or schools such as other subjects and in English subjects and also outsides universities such as in forum of religious harmony and other forums.

\section{Findings and Discussion}

\subsection{English Language Teaching in South-East Asia}

In Indonesia, English is Indonesia's first foreign language and is studied in high schools for a long time. In ELT Indonesia, the reorientation of ELT goals has been especially significant in the past few years. While today's Indonesian literacy rates with the success of national language teachings are just over 84 percent, Bahasa Indonesia, English learning has been regarded as less of a success[20]. In Indonesia English is more likely to be taught and studied only as a foreign language than in neighboring countries - such as Singapore, Hong Kong and Malaysia where English is commonly used as a second language. This means that English is taught and teached, not during everyday conversation, mostly in classrooms. English students 
in Indonesia have no ready access during their everyday lives outside the class room to use English as a means of communication[21]. However, there is a few institutions integrate Islamic moderation values into English language teaching in Indonesia.

Except in Indonesia, Islamic moderation values were not taught and integrated into English subjects such as in countries in South-East Asia. For example, In Cambodia, historically, between 1863 and 1953 when the French came into Cambodia. Three main languages were used when Cambodia gained independence: Pali, the Buddhist language; Khmer, its native language; and the colonizer's French language. The high school curriculum however provides teaching of English and French, and in September 1990, English was granted its official recognition as a subject. English is strongly institutionalized outside the school system by private initiative with 37 private English schools alone in the city of Phnom Penh. Furthermore, 15 secondary and elementary schools also have private English lessons. Although there is a strong interest in learning the language, English is still a lot to be wanted among school leavers. In the ELT market, reconstructive efforts included the mammoth tasks of teacher formation, design and formulation of the English curriculum of secondary and university schools, as well as the development of teaching materials. Two models have been developed in Cambodia to provide the teachers with English and teacher methodology: one is long-term training and another short-term rework[20]. However, no study in Cambodia found out that the Islamic moderation values were integrated into English language teaching.

In Malaysia, English is Malaysia's second language, although only the school curriculum teaches it as a subject. In all Malaysian schools, English is a mandatory subject, from the elementary level to the highest level. The program is primarily intended to provide students with the basic know-how and English is the language of language so as to allow it to be spoken and written both at school and abroad. In terms of exposure time in the curriculums, English is taught in national schools (i.e. from 1 to 3 years old) for 4 hours a week and in 4 to 6 years only less than 4 hours a week[20]. Nevertheless, there is no integration of Islamic moderation values in English langauge teaching in the school curriculum in Malaysia and in Myanmar as well. Though ELT has an interesting background in Myanmar, there's little The ELT development knowledge in Myanmar was published after 1985. By the late 1970s, the government was very worried about the drop in English. In addition, English was restored as the academic year 1986-87 medium of science and economics training in secondary and higher education levels[20].

In the Philippines, English is considered a second language. The Filipinos adopts a program of bilingual education at all levels of education. The Filipino and English languages are both. In international communication, English is preserved and the Filipino language is propagated as literate, a linguistic symbol of national unity and identity and a language for scholarly speech. The improvement of listening skills in the English primary education is stressed to talk, read and write. English is considered to be a foreign language in Thailand, but the English language is the most common in school in foreign countries. It has been taught in high schools all along. Since then, a transition has taken place. In the Eight National Education Plan 1997-2001, the time allocated to learning foreign languages has been "insufficient" as reported in Wongsothorn (1996). The goal of English Language teaching at the primary level is to allow students to learn English language skills that are necessary for communication, listening, speaking, reading and writing[20]. In both countries, the values of Islamic moderation were not included both in the curriculum and the classrooms.

In Vietnam, English played no important role in Vietnam 's development until only recently. Recently Vietnam was colonized like other countries on the Indo-China continent and eventually subjected to war ravages. Vietnam, however, understood quite early in its 
history the meaning of English. When Vietnam gained independence it was important for Vietnamese to learn English, besides English, changes in the foreign world and especially progress in science and technology. In schools today, Russian, French and English are the foreign languages taught at the upper secondary school level. English is the most common among the three students in the school curriculum[20].

In Singapore, In Singapore, the language of English is unique. It's one of three official languages. English, in all schools, polytechnics and universities; the language of management, courts, business and industry. English is the language of education. English is both a teaching medium and a thought method for many students for all purposes[22][20].

\subsection{Islamic Moderation in English Language Teaching}

Muslim scholars, deriving from the trilateral Arabic word wa sa qa, use the term Wasaqiyya to refer to Islam's principle or form of moderation. According to the Muslim belief, God revealed the revelation for the guidance of man whose aim is to free him from the darkness of ignorance to illuminate the light of truth, thus requiring him to apply the method of moderation as the significant source and essence of guidance in all walks of life. According to Muslim religious thinkers and Qur'anic exegetes, moderation is not limited to partial application or compliance of Islamic religious teachings or rulings or systems but is a holistic approach to be implemented by every person, community or nation in every aspect of life. Indeed, Islam is entirely based on the approach of moderation specifically extracted from the Scripture-based discourses of Muslim scholars. Anyone among Muslims who neglects moderation as a fact is regarded as neglecting Scripture fact and its holistic feature. The need and modality of the process of moderation is referred to in the Scriptures in a variety of places in relation to creed, acts of obedience, confession, legal rulings, commanding good and prohibiting bad, struggle for God's cause, human relationships and morality, acquisition of wealth and its expenditure and accountability of soul and passions[23]. Moderation should be implemented by every Muslim. Islamic moderation has a multidimensional meaning in life 's needs, psychology, education and religious dimensions that accommodate real life. This is a holistic philosophy of integrated approach and a combination of world and future needs for happiness. That is, this definition is an exclusive terminology consisting of many balancing principles. Overall, this definition affects a Muslim 's life and all humans. Islamic moderation becomes a Muslim identity because what Islam gives is part of religion. The concept of thought balance is to have a kufu understanding of Islam and it becomes the foundation of belief in life based on sharia, the framework of wisdom, various actions, worship style and relationships that transform the culture and character of individuals, whether in inter-social agreements, political meetings, religious doctrines and religious realities, community and national growth[24].

Islamic moderation in Islamic university curriculum include integration and internalization of science, strengthening the theology of Rahmatan lil alamin, the de-radicalization of religion through the strengthening of Javanese local wisdom, creating an anti radicalism curriculum, the evaluation of multicultural-oriented learning, integral Muslim personality development assistance program (P3KMI), value integration plurality in the curriculum and multicultural learning methods[25]. Instilling Islamic moderation values were implemented through group work activity in teaching English speaking in one of the Islamic university in Indonesia. The values include syuro (discussion), tasamuh (tolerant), tathawur wa ibtikar (dynamic, creative and innovative), musawah (egalitarian)[5]. 
Centered on what I discussed with a Southeast Asian ELT reality, I could draw some generalizations. First, no school or universities in Malaysia, the Philliphines, Singapore, or Vietnam did not integrate Islamic moderation values within English language teaching as they are more interested with the English programs, curriculum, syllbus and language teaching models. Only in Indonesia, a few Islamic institutions including Islamic universities or schools integrate Islamic moderation values in English language teaching.

\section{Conclusion}

The Islamic moderation values are the values such as tolerance, dynamicity, creativity, innovation, egalitarian, or moderation that every Muslim should possess. Islamic moderation values were not integrated into English language teaching in the coutries in South-East Asia except in Indonesia. In Indonesia, few Islamic institutions such as Islamic university or schools integrate Islamic moderation values in teaching English subjects in the classrooms although most Islamic religious study subjects are integrated with Islamic values and moderation values. Although few Islamic universities and schools integrate the Islamic moderation values in the English language teaching, there is no clear university or school polity to instruct teachers, lecturers or even coursebook writers to include the moderation values in the coursebooks.

\section{References}

[1] B. Z. Yanti and D. Witro, "Islamic Moderation as A Resolution of Different Conflicts of Religion," Andragogi J. Diklat Tek. Pendidik. dan Keagamaan, vol. 8, no. 1, pp. 446-457, 2020, doi: 10.36052/andragogi.v8i1.127.

[2] T. Islam and A. Khatun, "Islamic Moderation' in Perspectives: A Comparison Between Oriental and Occidental Scholarships," Int. J. Nusant. Islam, vol. 3, no. 2, pp. 69-78, 2015, doi: 10.15575/ijni.v3i2.1414.

[3] Siswanto, The Islamic Moderation Values on the Islamic Education Curriculum in Indonesia: A Content Analysis, vol. 8, no. 1. 2020.

[4] A. Saefudin and A. F. Al Fatihah, "Islamic Moderation Through Education Characters of Aswaja An-Nahdliyyah,” Nazhruna J. Pendidik. Islam, vol. 3, no. 2, pp. 160-179, 2020, doi: 10.31538/nzh.v3i2.594.

[5] A. Baidawi, W. Syakhirul, and R. Rabi'ah, "Integrating Islamic Moderation Values in Teaching Speaking through Group Activity," vol. 2, no. 2, pp. 137-148, 2020, doi: 10.19105/panyonara.v2i2.3667.

[6] M. E. Wijayanto, "the Integration of Islamic Values in Implementation of Learning English: Islamic Education Students Perspective," ETERNAL (English, Teaching, Learn. Res. Journal), vol. 6, no. 1, p. 18, 2020, doi: 10.24252/eternal.v61.2020.a2.

[7] A. Widodo, "Moderation Of Islamic Education As An Effort To Prevent Radicalism ( Case Study of FKUB Singkawang City, Kalimantan, Indonesia ) Introduction Society is not just a group of individuals who form a social community but is also a subject of education among," vol. 13, no. 2, 2019.

[8] F. Hoveyda, "Moderate islamists?," Am. Foreign Policy Interes., vol. 23, no. 2, pp. 5359, 2001, doi: 10.1080/108039201750463290.

[9] M. Marcellino, "English Language Teaching in Indonesia: A Continuous Challenge in 
Education and Cultural Diversity," TEFLIN J., vol. 17, no. 1, pp. 57-69, 2006, doi: 10.15639/teflinjournal.v19i1/57-69.

[10] A. Pandian, "English Language Teaching in Malaysia Today," Asia Pacific J. Educ., vol. 22, no. 2, pp. 35-52, 2002, doi: 10.1080/0218879020220205.

[11] C. Y. Mee, "English Language Teaching in Singapore," Asia Pacific J. Educ., vol. 22, no. 2, pp. 65-80, 2002, doi: 10.1080/0218879020220207.

[12] N. Davids, "Islam, moderation, radicalism, and justly balanced communities," $J$. Muslim Minor. Aff., vol. 37, no. 3, pp. 309-320, 2017, doi: 10.1080/13602004.2017.1384672.

[13] Mohd Shukri Hanafi, "The Wasatiyyah (Moderation) Concept in Islamic Epistemology: A Case Study of its Implementation in Malaysia," Int. J. Humanit. Soc. Sci., vol. 4, no. 9(1), pp. 51-62, 2014.

[14] U. Husna and M. Thohir, "Religious Moderation as a New Approach to Learning Islamic Religious Education in Schools," Nadwa, vol. 14, no. 1, p. 1999, 2020, doi: 10.21580/nw.2020.14.1.5766.

[15] G. N. Rohmah, L. Hanifiyah, and A. A. Ningsih, "Islamic Values Integration in English Lesson At Madrasah Tsanawiyah: Teachers' Beliefs and Practices," J. Bhs. Ling. Sci., vol. 11, no. 1, pp. 93-106, 2019, doi: 10.21274/1s.2019.11.1.93-106.

[16] E. M. Sofa, "Islamic Values in Higher Education Students' Communication in Edmodo Learning Platform," Edukasia Islam., vol. 3, no. 1, p. 50, 2018, doi: 10.28918/jei.v3i1.1678.

[17] L. Timulak, "Meta-analysis of qualitative studies: A tool for reviewing qualitative research findings in psychotherapy," Psychother. Res., vol. 19, no. 4-5, pp. 591-600, 2009, doi: 10.1080/10503300802477989.

[18] S. Thorne, L. Jensen, M. H. Kearney, G. Noblit, and M. Sandelowski, "Qualitative metasynthesis: Reflections on methodological orientation and ideological agenda," Qual. Health Res., vol. 14, no. 10, pp. 1342-1365, 2004, doi: 10.1177/1049732304269888.

[19] D. L. Finfgeld, "Metasynthesis: The state of the art - So far," Qual. Health Res., vol. 13, no. 7, pp. 893-904, Sep. 2003, doi: 10.1177/1049732303253462.

[20] H. W. Kam, "English language teaching in Southeast Asia: Continuity and change," Asian Englishes, vol. 1, no. 1, pp. 5-30, 1998, doi: 10.1080/13488678.1998.10800992.

[21] U. Sulistiyo, "English Language Teaching and Efl Teacher Competence in Indonesia," Igniting a Bright. Futur. EFL Teach. Learn. Multiling. Soc., vol. 4, no. 2, pp. 396-406, 2016, [Online]. Available: http://ejournal.unp.ac.id/index.php/selt/article/view/7001/5535.

[22] D. Matukhin and E. Zhitkova, "Implementing Blended Learning Technology in Higher Professional Education," Procedia - Soc. Behav. Sci., vol. 206, no. November, pp. 183 188, 2015, doi: 10.1016/j.sbspro.2015.10.051.

[23] T. Ushama, "Is islam a religion of moderation or extremism? a study of key islamic teachings," Asian Soc. Sci., vol. 10, no. 8, pp. 184-197, 2014, doi: 10.5539/ass.v10n8p184.

[24] A. M. Muthohar, "Islamic Moderation Model in Managing Mosque to Increase Philanthropy Fund at Jogokariyan Mosque Yogyakarta," RI'AYAH, vol. 4, no. 2, pp. 136-146, 2019.

[25] E. Ekawati, M. Suparta, K. Sirin, M. Maftuhah, and A. Pifianti, "Moderation of Higher Education Curriculum in Religious Deradicalization in Indonesia," TARBIYA J. Educ. Muslim Soc., vol. 6, no. 2, pp. 169-178, 2019, doi: 10.15408/tjems.v6i2.14886. 
